\title{
Seasonal variation in sperm characteristics of boars in southern Uruguay
}

\author{
Hugo Petrocelli', Carlos Batista1, Jaime Gosálvez²
}

\footnotetext{
${ }^{1}$ Universidad de la República, Facultad de Agronomía, Departamento de Producción Animal y Pasturas, Montevideo, Uruguay.

${ }^{2}$ Universidad Autónoma de Madrid, Facultad de Ciencias, Departamento de Biología, Madrid, España.
}

\begin{abstract}
The objective of this study was to evaluate the effects of season, natural photoperiod, and room temperature at the housing facility on boar semen characteristics in Uruguay $\left(34^{\circ} 66\right.$ 'S; $\left.56^{\circ} 29^{\prime} \mathrm{W}\right)$. For this purpose, 117 ejaculates, obtained from eight adult males collected through 12 consecutive months, were assessed for sperm viability, DNA integrity, abnormalities (total, primary, and secondary), ejaculate volume, and sperm concentration. Viability, total and primary abnormalities, volume, and sperm concentration were affected by season. Sperm viability, volume, and sperm concentration were affected by natural photoperiod. In general, autumn and the decreasing photoperiod had a negative impact on most of the semen characteristics, except for volume. Housing temperature did not affect semen characteristics. In boars living in temperate climates, semen quality is negatively affected during autumn and is related to photoperiod changes; however, the effects of temperature changes in housingdo not affect these seminal characteristics. In this scenario, seasonal differences in semen quality may have a negative effect on sow fertilization. Consequently, semen quality control especially during autumn is imperative for the best boar selection to be used for insemination purposes. Seasonal differences in semen quality may have a negative effect on sow reproductive performance. This issue will be addressed in a future investigation.
\end{abstract}

Key Words: boar, natural photoperiod, season, semen quality

\section{Introduction}

The reproductive output of pigs depends on many factors affecting both females and males. It is generally accepted that there is a large variation in the fertility results, mainly caused by farm- and sow-related parameters (Hanenberg et al., 2001). In southern Uruguay, seasonal variations in reproductive performance of swine herds are observed, with farrowing rate below $57 \%$ between November and February (Motta, 1991).

Several factors can be minimized by management, breeding, and artificial insemination. But there are certain variations in pig fertility explained by the boar and semen parameters. Many researchers have studied the relationship between semen parameters and fertility, with conflicting results (Tardif et al., 1999; Sellés et al., 2003; Popwell and Flowers, 2004; Ruiz-Sánchez et al., 2006; Broekhuijse et al., 2012).

Sperm quality is extremely important because each boar participates in a large number of services throughout the year. Thus, a good evaluation of the quality of the semen

Received September 5, 2014 and accepted November 27, 2014

Corresponding author: hugopetrocelli@gmail.com

http://dx.doi.org/10.1590/S1806-92902015000100001

Copyright $(2015$ Sociedade Brasileira de Zootecnia. This is an Open Access article distributed under the terms of the Creative Commons Attribution Non-Commercial License, which permits unrestricted non-commercial use, distribution, and reproduction in any medium, provided the original work is properly cited. of each male is imperative, and the examination should provide a reliable evaluation of the donor. Furthermore, the evaluation of seminal quality could help identify causes of low fertility.

The wild hog (Sus scrofa L.) has seasonal reproductive behaviour (Mauget and Boissin, 1987; Harayama et al., 1992; Kozdrowski and Dubiel, 2004). The domestication process of pigs has not completely eliminated this ancestral characteristic, which has been partially maintained in domestic boars (Claus et al., 1983; Auvigne et al., 2010), and it affects all of the semen characteristics (Kennedy and Wilkins, 1984).

Possible fluctuations in seminal quality are associated with factors such as breed (Rijsselaere et al., 2007), age (Stone et al., 2013), seasonality (Chemineau et al., 2008; Zhang et al., 2013), temperature (Thonneau et al., 1998), photoperiod (Mazzarri et al., 1970; Kozdrowski and Dubiel, 2004), and other factors of different etiology. All of these factors require careful control to attain the best semen quality for artificial insemination.

In temperate climates it seems important to take into account the complex environmental factors. Temperature and photoperiod show the most important effects on pigs (Kozdrowski and Dubiel, 2004; Rivera et al., 2005). It is suggested that photoperiod may play an important role, especially in temperate climates, due to the significant differences in day length over the year (Kunavongkrit et al., 2005). 
Sperm volume and concentration are lowest in the spring; they gradually increase during the summer, and reach a peak in late autumn (Trudeau and Sanford, 1986; Borg et al., 1993; Kozdrowski and Dubiel, 2004). Changes in the photoperiod cause variations in semen production (Mazzarri et al., 1970) and volume, and spermatozoa abnormalities (Sancho et al., 2004).

The aim of this investigation was to assess the effect of season, natural photoperiod, and annual temperature variations on sperm characteristics (routine and integrity of sperm DNA) in a group of boars of two different genetic backgrounds.

\section{Material and Methods}

The experimental work was carried out on a pig farm located in Uruguay $\left(34^{\circ} 66^{\prime} \mathrm{S} ; 56^{\circ} 29^{\prime} \mathrm{W}\right)$. The annual average temperature is $17{ }^{\circ} \mathrm{C}$, with seasonal variations. In the summer it varies between $17^{\circ} \mathrm{C}$ and $28^{\circ} \mathrm{C}$, with an average of $23{ }^{\circ} \mathrm{C}$; in the winter, between $6{ }^{\circ} \mathrm{C}$ and $14{ }^{\circ} \mathrm{C}$, with an average of $12{ }^{\circ} \mathrm{C}$. Autumn and spring show intermediate values. The annual rainfall is $1,100 \mathrm{~mm}$. The experiment was conducted through 12 consecutive months.

The studied semen was produced by eight boars that were an average of 1.5 years-old at the beginning of the experiment. Five males were Pen Ar Lan hybrids of a terminal male line P76 (ML) and three of the female line Gallia (FL).

Within the experimental period (one year) seasons were defined as follows: summer: January to March; autumn: April to June; winter: July to September; and spring: October to December. Each boar produced at least one ejaculate in every season. In the Southern Hemisphere, daylight decreases from December 22 to June 21 and increases from June 22 to December 21. Photoperiod (Figure 1) was defined as 'increasing' during winter and spring, and as 'decreasing' during summer and autumn. No artificial light was used.

According to Hughes and Varley (1986), the total duration of spermatogenesis is 41 days, so we started recording temperatures 50 days before the beginning of semen collection. The boar housing temperature was recorded hourly during 407 days. A total of 9,768 temperature records were obtained by the Sphere of Vernon $(12 \mathrm{~cm}$ diameter) with a thermal sensor (Thermochron iButton, Embedded Data Systems, Lawrenceburg, KY, USA) inside, utilised where the boars were housed. Average daily temperature (ADT) and average maximum daily temperature (MDT) were calculated from the above mentioned records.
One hundred and seventeen ejaculates obtained from the eight boars were included in the analysis. The semen was collected with the gloved-hand method. The ejaculate was collected and filtered with gauze during collection. The sample was immediately placed in a $37^{\circ} \mathrm{C}$ bath. It was then diluted using a commercial semen extender (M III Androstar ${ }^{\circledR}$ Plus, MinitubeAbfüll-und LabortechnikGmbH \& Co. KG, Germany). To determine the number of doses to be prepared per ejaculate, a primary evaluation of the volume and a subjective approximation of motility and a subjective estimation of the number of spermatozoa were performed at the farm; using these data, the number of doses to be prepared was calculated. Motility was scored 1 (worst) to 5 (best), and ejaculates scoring 3 or less were discarded. The samples for evaluation of semen characteristics were prepared and transferred from the farm to the laboratory using a remote container thermally adjusted to $16{ }^{\circ} \mathrm{C}$. Once in the laboratory, the following characteristics were evaluated: Sperm concentration (SC) (Neubauer chamber); Viability: sperm viability (eosinnigrosin); Sperm DNA fragmentation (DFI, \%) (Halomax kit; Halotech, Madrid, Spain); and Sperm morphology, using primary abnormalities (PA, \%; abnormalities of the head, intermediate pieces and insertion of the queue), secondary abnormalities (SA, \%; other sperm abnormalities), and total abnormalities (TA, $\%=\mathrm{PA} \%+\mathrm{SA} \%$ ). Sperm DNA fragmentation was evaluated using fluorescence microscopy (Olympus fluorescence microscope BX41TF, Olympus Corporation, Tokyo, Japan) according to the methodology, and Sperm Chromatin Dispersion test, described by Enciso et al. (2006). The sperm DNA fragmentation was calculated as the percentage of damaged spermatozoa and the sperm abnormalities as the percentage of abnormal cells, both in the sample estimated by examining 200 spermatozoa.

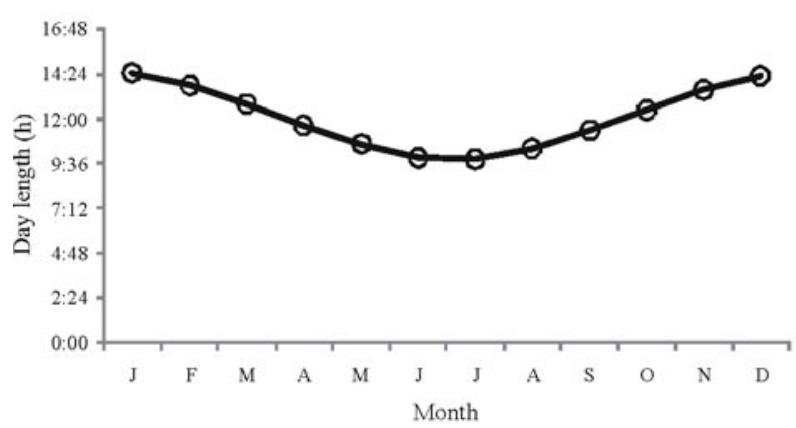

Data obtained from the Weather Station of the Faculty of Agriculture located near the farm.

Figure 1 - Variation in natural photoperiod: mean monthly day length. 
Boars that had at least one ejaculate at each season were evaluated (Table 1). Because 'Season' and 'Photoperiod' are not independent, they were separately dealt with in the analyses. The fitted model was:

$$
\mathrm{Y}_{\mathrm{ijkl}}=\mu+\mathrm{M}(\mathrm{TG})_{\mathrm{ij}}+\mathrm{GT}_{\mathrm{j}}+\mathrm{S}_{\mathrm{k}}+\mathrm{E}_{\mathrm{ijk} \mathrm{k}} \text {, }
$$

in which $\mu=$ mean; $\mathrm{M}(\mathrm{GT})_{\mathrm{ij}}$ = value of the $\mathrm{i}$-th male within the $j$-th genetic type; $S_{k}=$ value of the k-th season (or k-th photoperiod); and $\mathrm{E}_{\mathrm{ijkl}}=$ experimental error.

Semen volume and SC were analysed using the MIXED procedure of SAS (Statistical Analysis System, version 9.0) software. Viability, DFI, and abnormalities (TA, PA and SA) were not distributed normally and were analysed using the GLIMMIX procedure of SAS (Statistical Analysis System, version 9.0), fitting a multinomial distribution. It should be stressed, however, that the results from the latter analysis were very similar to those obtained treating these variables as if they were normally distributed.

The correlation (Pearson's) between temperature records and seminal characteristics was calculated using

Table 1 - Number of ejaculates studied from each male in each season

\begin{tabular}{lccccc}
\hline \multirow{2}{*}{ Males } & Total n & \multicolumn{5}{c}{ Season } \\
\cline { 3 - 6 } & & Summer & Autumn & Winter & Spring \\
\hline M1 & 21 & 4 & 4 & 7 & 6 \\
M2 & 23 & 6 & 4 & 7 & 6 \\
M3 & 10 & 4 & 1 & 1 & 4 \\
M4 & 11 & 2 & 1 & 1 & 7 \\
M5 & 24 & 6 & 4 & 7 & 7 \\
Male line & 89 & 22 & 14 & 23 & 30 \\
F6 & 10 & 2 & 2 & 3 & 3 \\
F7 & 9 & 2 & 1 & 2 & 4 \\
F8 & 9 & 3 & 1 & 2 & 3 \\
Female line & 28 & 7 & 4 & 7 & 10 \\
Total & 117 & 29 & 18 & 30 & 40 \\
\hline
\end{tabular}

the CORR procedure of SAS (Statistical Analysis System, version 9.0)

\section{Results}

Autumn had the worst values for most sperm characteristics, with the exception of volume (Table 2). Differences were detected between seasons in viability, total and primary abnormalities, volume, and sperm concentration. In autumn viability was low, significantly differing from the other seasons. For TA and PA, low values were observed during the autumn and spring and differed from those observed during winter and summer.

Increasing photoperiod resulted in the best values in all seminal characteristics. Viability, volume and sperm concentration showed differences between photoperiods. Volume was the only characteristic for which decreasing photoperiod was associated with a greater value.

The recorded temperatures during the experimental period were an absolute maximum temperature of $32{ }^{\circ} \mathrm{C}$ and an absolute minimum temperature of $5.5{ }^{\circ} \mathrm{C}$. Only $0.72 \%$ (71) of the temperature records were higher than $28.9{ }^{\circ} \mathrm{C}$, which occurred during December (20 days), January (30 days), and February (21 days) (Figure 2). If we define a heat wave as five consecutive hours or more at $29^{\circ} \mathrm{C}$ or higher, only six episodes (two in December, three in January, and one in February) were recorded. However, in all of these episodes, the temperature always decreased at least during the night. Regarding the MDT, 13 days in which it exceeded $29{ }^{\circ} \mathrm{C}$ were recorded (two in January, five in February, four in March, and two in April).

The correlations between temperature (ADT or MDT) and seminal characteristics were low and non-significant,

Table 2 - Mean values and standard deviation for semen characteristics by season, photoperiod and genetic type

\begin{tabular}{|c|c|c|c|c|c|c|c|c|}
\hline & $\mathrm{n}$ & Vitality (\%) & DFI (\%) & TA $(\%)$ & PA $(\%)$ & SA $(\%)$ & $\begin{array}{l}\text { Volume } \\
(\mathrm{mL})\end{array}$ & $\begin{array}{c}\mathrm{SC} \\
\left(\times 10^{6} \cdot \mathrm{mL}^{-1}\right)\end{array}$ \\
\hline \multicolumn{9}{|l|}{ Season } \\
\hline Summer & 29 & $85.2(1.27) \mathrm{b}$ & $3.6(0.83)$ & $13.2(1.72) \mathrm{a}$ & $3.6(1.08) \mathrm{a}$ & $9.6(1.46)$ & $327.0(12.93) \mathrm{ab}$ & $260.0(18.95) \mathrm{b}$ \\
\hline Winter & 30 & $88.2(1.44) \mathrm{a}$ & $3.7(0.72)$ & $10.2(1.42) \mathrm{a}$ & $1.1(0.54) \mathrm{a}$ & $9.1(1.25)$ & $310.0(13.64) \mathrm{b}$ & $309.9(18.57) \mathrm{a}$ \\
\hline Spring & 40 & $86.1(1.52) a b$ & $6.1(0.98)$ & $18.8(2.25) \mathrm{b}$ & $10.5(1.56) \mathrm{b}$ & $8.3(1.28)$ & $293.8(10.35) \mathrm{c}$ & $289.9(17.13) \mathrm{ab}$ \\
\hline \multicolumn{9}{|l|}{ Photoperiod } \\
\hline \multicolumn{9}{|l|}{ Genetic type } \\
\hline Male line & 89 & $85.2(0.90)$ & $5.5(0.70)$ & $17.6(1.21) \mathrm{a}$ & $6.9(0.86)$ & $10.7(0.84) \mathrm{a}$ & $301.8(7.82) \mathrm{a}$ & $293.6(11.08) \mathrm{a}$ \\
\hline Female line & 28 & $86.4(1.43)$ & $5.6(0.90)$ & $9.2(1.22) \mathrm{b}$ & $4.6(1.12)$ & $4.6(0.50) \mathrm{b}$ & $349.4(11.76) \mathrm{b}$ & $222.2(14.81) b$ \\
\hline Total & 117 & $85.5(0.78)$ & $5.5(0.63)$ & $15.5(1.06)$ & $6.3(0.73)$ & $9.2(0.72)$ & $313.4(6.92)$ & $276.2(9.72)$ \\
\hline
\end{tabular}

Means with different letters within a column differ significantly $(\mathrm{P}<0.05)$. Comparisons can be made between seasons or photoperiod.

DFI - sperm DNA fragmentation; TA - total abnormalities; PA - primary abnormalities; SA - secondary abnormalities; SC - sperm concentration. 


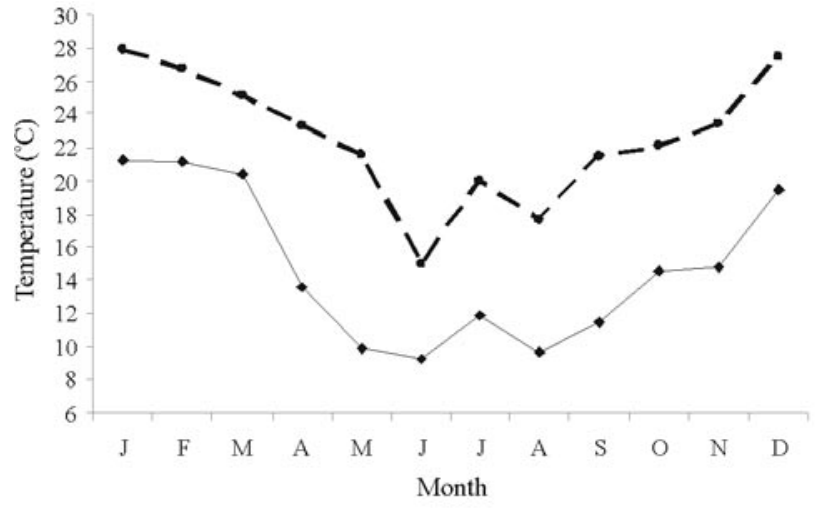

Average maximum (dashed line) and minimum (continuous line).

Figure 2 - Monthly variation in the boar housing temperature during the experiment period.

except in the case of viability, in which it was low and negative ( -0.1838 and -0.1891 , respectively). Plots of temperature records against semen characteristics visually confirmed the lack of association.

Quantification of the genetic-type effects was not a primary objective in the present study. They were fitted in order to enable a more precise insight into the effects of season and photoperiod. There were significant differences between genetic types in TA, SA, volume, and SC (Table 2).

Before calculating correlations between seminal characteristics, they were plotted for each season or photoperiod. The only significant correlation found was between volume and $\mathrm{SC}(\mathrm{r}=-0.39630, \mathrm{P}=0.0023)$.

\section{Discussion}

The seasonal nature of reproduction in wild pigs has been well known (Mauget and Boissin, 1987; Kozdrowski and Dubiel, 2004). It is also present to some extent in domestic pigs, where it may constitute a problem in farming conditions.

In our study seasonality affected several seminal characteristics. In autumn, boars had the worst semen quality, whereas the opposite was true for winter. The highest volume was observed in autumn and the lowest in spring, which is in agreement with reports by other researchers (Wolf and Smital, 2001; Kozdrowski and Dubiel, 2004; Frydrychová et al., 2007). Semen plasma is a product of accessory glands (Pérez-Pé et al., 2001).The increasing activity of the accessory sex glands in autumn observed by Ciereszko et al. (2000) could explain the higher volume ejaculated in this season.

Viability was also affected by season. Autumn was significantly worse than the other seasons, whereas winter was the best. This finding is in contrast with an earlier experiment, where no differences in viability were found between seasons (Sancho et al., 2004; Rivera et al., 2005).

The incidence of abnormalities was higher in autumn than in winter and summer. This is not in agreement with earlier studies performed in the Southern Hemisphere and at similar latitudes in outdoors systems (Ambrogi, 1999) or in housing systems (Elhordoy, 1999; Petrocelli et al., 2003); the aforementioned authors observed a higher percentage of abnormalities in the summer. However, unlike in these experiments, in our work temperatures at the boar housing were not high enough to not impose any heat stress (Figure 2).

The DNA fragmentation was not significantly different between seasons. This aspect has been reported in other animals such as the goat (Delgadillo et al., 1991; Avdi et al., 1993; López-Fernández et al., 2001).

The wild hog is a short-day breeder. Testicular activity increases when the day length is shorter than 12 hours. We observed a high SC in winter and a low value in summer, which is in agreement with what has been reported for wild hogs (Mauget and Boissin, 1987; Kozdrowski and Dubiel, 2004). Kozdrowski and Dubiel (2004) suggested that the functioning of the reproductive organs of the boar is seasonal, controlled by photoperiod, as is the case with the wild pigs. However, this is not conclusive, since other observations have not revealed a clear effect of the photoperiod on domestic boars (Sancho et al., 2004).

The effect of season is frequently attributed to a combination of two factors: photoperiod and temperature (Ciereszko et al., 2000). In our study, no significant correlations between seminal characteristics and temperature were found. According to Hoffman and Landeck (1999), temperature and photoperiod affect the hypothalamichypophysis-gonadal axis regulating spermatozoa production and maturation in the epididymis. It has also been reported that a daily variation in temperature (difference between maximum and minimum temperature) greater than $10^{\circ} \mathrm{C}$ has a marked effect on sperm production (Kunavongkrit et al., 2005); in our study variations of such magnitude were only observed in three separate days. Because the temperature at the boar housing (Figure 2) did not reach values that could cause heat stress and affect spermatogenesis, we may assume that the main effect of the season was due to photoperiod.

At the latitude where the present experiment was conducted, the day length varies between $9.50 \mathrm{~h}$ and $14.30 \mathrm{~h}$. Days are shorter than $12 \mathrm{~h}$ from March 24th (autumn - decreasing photoperiod) to September 18th (winter - increasing photoperiod) (Figure 1). 
Most research has been conducted in the Northern Hemisphere and at varying latitudes. Despite these differences, sperm quality was similar and correlated with the photoperiod in a manner similar to that in our study. The decreasing photoperiods during autumn, but not the increasing photoperiods of spring, impaired testicular function (Sancho et al., 2004). Some authors observed that decreasing day length was the main environmental factor affecting the testicular function of boars from temperate climates (Schopper et al., 1984). These results are consistent with ours. We observed that autumn was the worst season for sperm quality, a time at which photoperiod is decreasing. However, they disagree with other studies where the highest activity was observed in late autumn and winter in wild pigs (Kozdrowski and Dubiel, 2004) or late autumn in domestic pigs (Knecht et al., 2013). We observed an effect of photoperiod on several semen characteristics. The worst values were observed during the decreasing photoperiod. Volume was the only characteristic that was higher during the decreasing period, in agreement with the studies of Trudeau and Sanford (1986) and Knecht et al. (2013), who studied photoperiod. However, they contrast with Greenberg and Mahone (1981) and Sancho et al. (2004), who, working with an artificially induced photoperiod, observed an increased volume with increasing day length. The greater ejaculate volume may be explained by the same reasons mentioned above for the autumn.

The sperm concentration is affected by photoperiod (Ciereszko et al., 2000). In our study, the sperm concentration was significantly higher during increasing photoperiod. This agrees with Sancho et al. (2004), who observed a $50 \%$ lower sperm production in boars under a decreasing photoperiod than boars under an increasing photoperiod. Our results can be partially explained by the negative correlation observed between $\mathrm{SC}$ and volume in both photoperiods. Earlier studies have also reported increased testosterone concentrations in boars exposed to long photoperiods and suggested that steroid genesis, and thus the sperm concentration, is also influenced by the photoperiod (Minton et al., 1985).

Viability was also affected by photoperiod, showing the highest value when it was increasing. This is not consistent with what Sancho et al. (2006) observed working with artificial light regimes, namely, no differences in viability.

In earlier work, Sancho et al. (2004) observed differences due to photoperiod that were lower than $1 \%$ in semen abnormalities. This is consistent with our results. We found differences of $1 \%$ which were not significant between photoperiods.
The effects of boar and genetic type on semen characteristics have been reported earlier (Smital, 2009; Wysokińska et al., 2009). Due to the low number of boars we only make considerations about genetic type. Heterosis may result in an increase in testicular mass, affecting the number of spermatozoa produced (Smital, 2009). However, a negative relationship between testis mass and number of spermatozoa has also been reported (Borg et al., 1993).

The present study was conducted at a commercial farm where all the males with possible reproductive problems were eliminated, meaning that no animals could be evaluated for reproductive problems. Therefore, the observed differences between boars may be smaller than in an intact population.

We observed a large individual variation in DFI (80\%); for abnormalities, the variation was between $56 \%$ and $78 \%$; for volume and SC, they were around $35 \%$; and for viability, only $4 \%$. Similar results have been reported in previous research in boars (Boe-Hansen et al., 2005; De Ambrogi et al., 2006; Enciso et al., 2006) and in horses (López-Fernández et al., 2007).

Our data were collected under commercial conditions. The boars were assessed for general soundness, and those showing any sign that may suggest a reproductive problem were culled before our study was conducted.

\section{Conclusions}

All seminal characteristics evaluated exhibit a large seasonal component. The temperature in the boar housing facility reached values that do not pose a threat from a heat stress viewpoint. Therefore, we suggest that the season effect is mainly the consequence of differences in natural photoperiod. Semen quality is mostly affected during autumn (decreasing photoperiod). Such seasonal differences in semen quality could have a negative effect on sow reproductive performance. This issue is being addressed at present. Preliminary results from an experiment in progress suggest an effect of sperm quality on reproductive performance.

\section{Acknowledgments}

The authors thank Dr. Raúl Ponzoni for the help with the statistical analysis and drafting of the manuscript, as well as the owners of the "Torre del Oso" farm and its staff. This study was funded by CSIC (Comisión Sectorial de Investigación Científica, Universidad de la República). 


\section{References}

Ambrogi, A. 1999. Enfermedades y problemas respiratorios en sistemas al aire libre formas de control. p.67-9. In: 2o Encontro do Conesul de técnicos especialistas em Siscal e 2o Simpósio sobre Siscal. Concórdia, SC, Brasil.

Auvigne, V.; Leneveu, P.; Jehannin, C.; Peltoniemi, O. and Salle, E. 2010. Seasonal infertility in sows: A five year field study to analyze the relative roles of heat stress and photoperiod. Theriogenology 74:60-66.

Avdi, M.; Driancourt, M. A. and Chemineau, P. 1993. Variations saisonnières du comportement d'oestrus et de l'activité ovulatoire chez les brebis Chios et Serres en Grèce. Reproduction Nutrition Développement 33:15-24.

Boe-Hansen, G. B.; Ersbøll, A. K.; Greve, T. and Christensen, P. 2005. Increasing storage time of extended boar semen reduces sperm DNA integrity. Theriogenology 63:2006-2019.

Borg, K. E.; Lunstra, D. D. and Chistenson, R. K. 1993. Semen characteristics, testicular size, and reproductive hormone concentration in mature Duroc, Meishan, Fengjing, and Minzhu boars. Biology Reproduction 49:515-521.

Broekhuijse, M. L. W. J.; Šoštarić, E.; Feitsma, H. and Gadella, B. M. 2012. The value of microscopic semen motility assessment at collection for a commercial artificial insemination centre, a retrospective study on factors explaining variation in pig fertility. Theriogenology 77:1466-1479.

Chemineau, P.; Guillaume, D.; Migaud, M.; Thiéry, J. C.; PellicerRubio, M. T. and Malpaux, B. 2008. Seasonality of reproduction in mammals: intimate regulatory mechanisms and practical implications. Reproduction Domestic Animal 43(Suppl. 2):40-47.

Ciereszko, A.; Ottobre, J. S. and Glogowski, J. 2000. Effects of season and breed on sperm activity and semen quality of boars. Animal Reproduction Science 64:89-96.

Claus, R.; Schopper, D. and Wagner, H-G. 1983. Seasonal effect on steroids in blood plasma and seminal plasma of boars. Journal of Steroid Biochemestry 19:725-729.

De Ambrogi, M.; Spinaci, M.; Galeati, G. and Tamanini, C. 2006. Viability and DNA fragmentation in differently sorted boar spermatozoa. Theriogenology 66:1994-2000.

Delgadillo, J. A.; Leboeuf, B. and Chemineau, P. 1991. Decrease in the seasonality of sexual behavior and sperm production in bucks by exposure to short photoperiodic cycles. Theriogenology 36:755-770.

Elhordoy, D. 1999. Problemas y enfermedades reproductivas más comunes en cerdos de Uruguay. p.78-79. In: 2o Encontro do Conesul de técnicos especialistas em Siscal e 2o Simpósio sobre Siscal. Concórdia, SC, Brasil.

Enciso, M.; López-Fernández, C.; Fernández, J. L.; García, P.; Gosálvez, A. and Gosálvez, J. 2006. A new meted to analyze boar sperm DNA fragmentation under bright-field or fluorescence microscopy. Theriogenology 65:308-316.

Frydrychová, S.; Lustyková, A.; Čerovyský, J.; Lipenský, J. and Rozkot, M. 2007. Seasonal changes of boars semen production. Research Pig Breeding 1:31-33.

Greenberg, L. G. and Mahone, J. P. 1981. The effect of 15-h photoperiod on reproductive function in boars at 2, 3, 4 or 5 months of age. Canadian Journal of Animal Science 61:925-934.

Hanenberg, E. H. A. T.; Knol, E. F. and Merks, J. W. M. 2001. Estimates of genetic parameters for reproductions traits at different parities in Dutch Landrace pigs. Livestock Production Science 69:179-186.

Harayama, H.; Kanda, S. and Kato, S. 1992. Influence of season on characteristics of epididymal and ejaculated semen on Meishan boars. Theriogenology 38:491-500.
Hoffman, B. and Landeck, A. 1999. Testicular endocrine function, seasonality and semen quality of the stallion. Animal Reproduction Science 57:89-98.

Hughes, P. E. and Varley, M. A. 1986. Reproducción del cerdo. Zaragoza, Acriba.

Kennedy, B. W. and Wilkins, J. N. 1984. Boar, breed and environmental factors influencing semen characteristics of boars used in artificial insemination. Canadian Journal of Animal Science 64:833-843.

Knecht, D.; Środoń, S.; Szulc, K. and Duziński, K. 2013. The effect of photoperiod on selected parameters of boar semen. Livestock Science 57:364-371.

Kozdrowski, R. and Dubiel, A. 2004. The effect of season on the properties of wild boar (Sus scrofa L.) semen. Theriogenology $80: 281-289$

Kunavongkrit, A.; Suriyasomboom, A.; Lundeheim, N.; Heard, T. W. and Einarsson, S. 2005. Management and sperm production of boars under differing environmental conditions. Theriogenology 63:657-667.

López-Fernández, C.; Crespo, F.; Arroyo, F.; Fernández, J. L.; Arana, P.; Johnston, S. D. and Gosálvez, J. 2007. Dynamics of sperm DNA fragmentation in domestic animals II. The stallion. Theriogenology 68:1240-1250.

López-Fernández, C.; Johnston, S. D.; Gosálbez, A. and Gosálvez, J. 2001. Seasonal changes in sperm DNA fragmentation of MurcianoGranadina goats: The compelling case for dynamic assessment. Small Ruminant Reseaech 100:50-53.

Mauget, R. and Boissin, J. 1987. Seasonal changes in testis weight and testosterone concentration in the European wild boar (Sus scrofa L.). Animal Reproduction Science 13:67-74.

Mazzarri, G.; du Mesnil du Buisson, F. and Ortavant, R. 1970. Acción de la temperatura y de la luz sobre la producción y el poder fecundante de los espermatozoides del verraco. Agronomía Tropical 20:173-184.

Minton, J. E.; Fent, R. W. and Wettemann, R. P. 1985. Influence of the duration of photoperiod on growth, testicular characteristics and endocrine function of boars. Domestic Animal Endocrinology 2:53-59.

Motta, A. 1991. Evaluación de los efectos de la estación y del tipo de servicio sobre la eficiencia reproductiva en una granja porcina del sur del país. Tesis (Grado). UdelaR, Facultad de Agronomía, Montevideo, Uruguay.

Pérez-Pé, R.; Cebrián-Pérez, J. A. and Muiño-Blanco, T. 2001. Semen plasma proteins prevent cold-shock membrane damage to ram spermatozoa. Theriogenology 56:425-434.

Petrocelli, H.; Pérez-Clariget, R.; Franco, J.; Haretche, J.; Burgueño, J. and López, A. 2003. Efecto de la raza, mes de colección y de servicio sobre la calidad seminal de verracos y desempeño al parto de cerdas inseminadas artificialmente. Agrociencia 7:60-67.

Popwell, J. M. and Flowers, W. L. 2004. Variability in relationships between semen quality and estimates of in vivo and in vitro fertility in boars. Animal Reproduction Science 81:97-113.

Rijsselaere, T.; Maes, D.; Hoflack, G.; de Kruif, A. and Van Soom, A. 2007. Effect of body weight, age and breeding history on canine sperm quality parameters measured by the Hamilton-Thorne analyzer. Reproduction Domestic Animal 42:143-148.

Rivera, M. M.; Quintero-Moreno, A.; Barrera, X.; Palomo, M. J.; Rigau, T. and Rodríguez-Gil, J. E. 2005. Natural Mediterranean photoperiod does not affect the main parameters of boar-semen quality analysis. Theriogenology 64:934-946.

Ruiz-Sánchez, A. L.; O’Donoghue, R.; Novak, S.; Dyck, M. K.; Cosgrove, J. R.; Dixon, W. T. and Foxcroft, G. R. 2006. The predictive value of routine semen evaluation and IVF technology for determining relative boar fertility. Theriogenology 66:736-748. 
Sancho, S.; Pinart, E.; Briz, M.; Garcia-Gil, N.; Badia, E.; Bassols, J.; Kádár, E.; Pruneda, A.; Bussalleu, E.; Yeste, M.; Coll, M. G. and Bonet, S. 2004. Semen quality of postpubertal boars during increasing and decreasing natural photoperiods. Theriogenology 62:1271-1282.

Sancho, S.; Rodríguez-Gil, J. E.; Pinart, E.; Briz, M.; García-Gil, N.; Badia, E.; Bassols, J.; Pruneda, A.; Bussalleu, R.; Yeste, M.; Casa, I.; Palomo, M. J.; Ramió, L. and Bonet, S. 2006. Effects of exposing boars to different artificial light regimens on semen plasma markers and "in vivo" fertilizing capacity. Theriogenology 65:317-331.

Schopper, D.; Gaus, J.; Claus, R. and Bader, H. 1984. Seasonal changes of steroid concentrations in seminal plasma of a European wild boar. Acta Endocrinology 107:425-427.

Sellés, E.; Gadea, J.; Romar, R.; Matás, C. and Ruiz, S. 2003. Analysis of in vitro fertilizing capacity to evaluate the freezing procedures of boar semen and to predict the subsequent fertility. Reproduction Domestic Animal 38:66-72.

Smital, J. 2009. Effects influencing boar semen. Animal Reproduction Science 110:335-346.

Stone, B. A.; Alex, A.; Werlin, L. B. and Marrs, R. P. 2013. Age thresholds for changes in semen parameters in men. Fertility Sterility 100:952-958.
Tardif, S.; Laforest, J-P.; Cormier, N. and Bailey, J. L. 1999. The importance of porcine sperm parameters on fertility in vivo. Theriogenology 52:447-459.

Thonneau, P.; Bujan, L.; Multigner, L. and Mieusset, R. 1998. Occupational heat exposure and male fertility: a review. Human Reproduction 13:2122-2125.

Trudeau, V. and Sanford, L. M. 1986. Effect of season and social environment on testis size and semen quality of the adult Landrace boar. Journal of Animal Science 63:1211-1219.

Wolf, J. and Smital, J. 2009. Quantification of factors affecting semen traits in artificial insemination boars from animal model analyses. Journal of Animal Science 87:1620-1627.

Wysokińska, A.; Kondracki, S.; Kowalewski, D.; Adamiak, A. and Muczynska, E. 2009. Effect of seasonal factors on the ejaculate properties of crossbred Duroc x Pietrain and Pietrain x Duroc boars as well as purebred Duroc and Pietrain boars. Bulletin of the Veterinary Institute in Pulawy 53:677-685.

Zhang, X. Z.; Liu, J. H.; Sheng, H. Q.; Wu, H. J.; Wu, Y.; Yao, K. S.; Lu, J. C. and Zhang, F. B. 2013. Seasonal variation in semen quality in China. Andrology 1:639-643. 